\title{
Use of Barcode Based Traditional Games in Improving Student Learning Outcomes in Learning Citizenship Education (PPKN)
}

\author{
Fandi H. Binggo ${ }^{1}$, Amna N. Noho \\ ${ }^{1}$ Elementary School Teacher Education Study Program, Faculty of Teacher Training and \\ Education, Muhammadiyah University of Gorontalo, Indonesia
}

Received: October 26, 2020

Revised: November 3, 2020

Accepted: November 5, 2020

\begin{abstract}
This study collaborates between traditional games and technology. The purpose of this study was to improve student learning outcomes in PPKN (Citizenship Education) learning through barcode-based traditional games tumbawa. This type of research is classroom action research. This research was conducted because based on preliminary observations, the results of students' daily tests in PPKn learning were still low, from 25 students, 25 students, only 12 people or $48 \%$ had good learning outcomes. The procedures used in this study consisted of planning, implementing, observing, reflecting. This research was conducted in two cycles of action. The data collection methods used were tests, observation, interviews, and documentation. In analyzing the data used a qualitative descriptive method assisted by the calculation of the percentage. The targeted research output is the national journal published in the internationally accredited journal 5. The level of technology readiness used is in the field of education (TKT 2). This research is expected to create a learning atmosphere and a learning process that attracts students' attention so that it provides better learning achievement than before.
\end{abstract}

Keywords: Traditional Games, Tumbawa, Barcode, Learning Outcomes.

\section{Introduction}

The rapid development of science and technology has an impact on aspects of human life in world competition. Therefore, as a nation to face today's competition it should be necessary to increase human resources. Increasing human resources must be planned, directed, and systematic, in order to produce outputs that contribute to competition in the present and in the future (Dussault \& Dubois 2003; Narasimhan, 2004; Daley, 2012).

Talking about improving human resources, one of the things that play an important role in education. Improving the quality of education is something that is integrated with improving the quality of human resources. This is of course in accordance with the spirit and goals of national education stipulated in Law no. 20 of 2003 concerning the National Education System which aims to develop the potential of students to become human beings who believe in God Almighty, have a noble character, are healthy, knowledgeable, capable, creative, independent and become democratic and responsible citizens.

However, based on preliminary observations of learning on the theme of the beauty of togetherness in elementary school, the Laboratory of UNG, it is still low, from 25 students only 12 people or $48 \%$ have good learning outcomes, while 13 people or $52 \%$ have low learning outcomes. This is due to the low quality of learning that is not well planned and designed as a result, learning is of less quality and attracts students to learn. For that, we need an innovation in learning that can have an impact on students, one of which is the use of the traditional tumbawa game. 
The traditional Tumbawa game is a game played by matching or pairing objects with a lid, for example, a bottle with a lid. Research conducted by Yudiwinata (2014) shows that children who play traditional games have much more developed abilities, including the ability to work together, sportsmanship, the ability to build strategies, and dexterity. Traditional games according to Dharmamulya (2010) explain that traditional games are a form or form of culture that characterizes a particular culture.

Meanwhile, according to Danandjaja Achroni (2012), traditional games are a form of children's play, which are circulated orally among certain collective members, are traditional in form and have been passed down from generation to generation, and have many variations. This is emphasized again by Husain (2013) that traditional games are games that have been played by children who come from an area traditionally, namely the game is inherited from one generation to the next.

Kurniati (2016) states that traditional folk games are cultural products of great value for children in the context of fantasizing, recreation, exercising which is also a means of practicing for social life, skills, politeness, and dexterity. Traditional games in turn make children able to socialize well in society. (Sujarno, 2013).

Initially, the game used shells that have their closing pairs and were played in coastal areas. Reportedly, this game was brought by traders from Ternate who often dock in Sumalata. This game requires the player's accuracy to match similar objects, colors but with different motives. Game participants (3-5 people) start the game by stacking the covered objects in one place three meters from where they are standing.

The traditional game of tumbawa. If it is related to PPKn (Citizenship Education) material, this game fits perfectly with the material of the Beautiful Diversity of My Country. In the material about the beauty of the diversity of my country, students will match or pair the diversity of cultures with the origin of the province or region in Indonesia. This article shows the use of Barcode-based traditional Tumbawa games to improve student learning outcomes in PPKn learning.

\section{Methods}

The research used by researchers in this study is Classroom Action Research (PTK). Classroom Action Research carried out with the aim of improving and improving the learning process in the classroom. Classroom action research is research that is carried out systematically and professionally and then reflects on the various actions taken by the teacher with participants, to improve the conditions of the learning being carried out.

The classroom action research design used in this study is the model of Kemmis et al (2013). Arikunto (2010) explains that in one cycle there are four steps, namely (1) planning, (2) implementation, (3) observation, (4) reflection. Data collection techniques, namely observation, tests, and documentation. Then the data analysis used in this study is qualitative which refers to the opinion of Miles and Huberman which includes 3 steps, namely Data Reduction, Data Presentation, and Conclusion Drawing.

\section{Results and discussion}

According to Daulima (2006), this game is to match objects with a lid, for example, a pot or bowl with a lid. Initially, the game used shells that have their closing pairs and were played in coastal areas. Reportedly, this game was brought by traders from Ternate who often dock in Sumalata. This game requires the player's accuracy to match similar objects, colors but with different motives. Game participants (3-5 people) start the game by stacking the covered objects in one place three meters from where they are standing. The game stops after the 
count of ten. The participant who has the most number of correct matches wins. Children can hone their agility and accuracy in this game.

The traditional game of tumbawa in learning is named to the material with the following description:

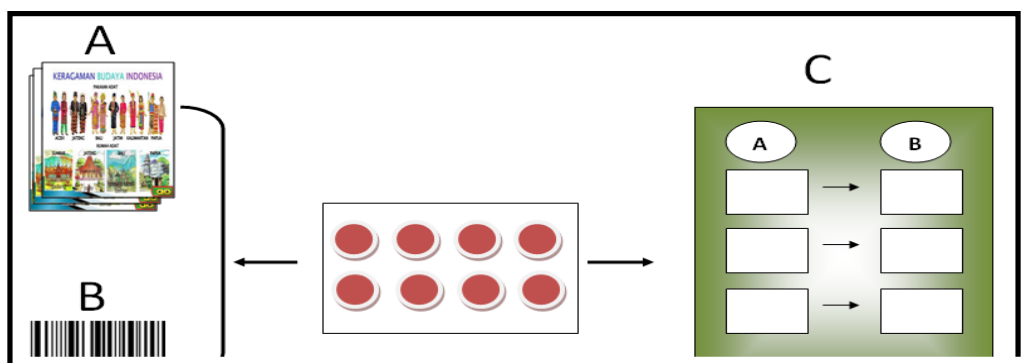

Figure 1. Tumbawa Games in Learning

Caption:

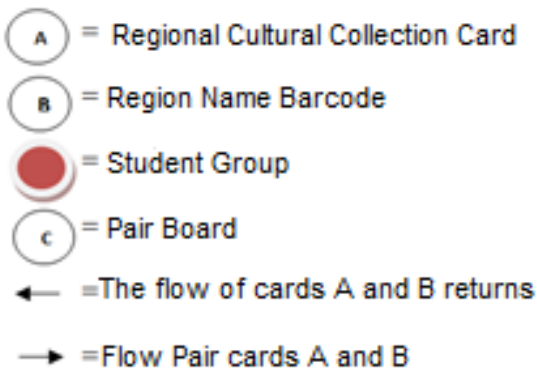

\section{Results of Teacher Observations and Student Activities in the Use of Barcode-Based Traditional Games Tumbawa Cycle I}

In the implementation of the first cycle of research, the teacher took steps in the implementation of the research using the traditional game of tumbawa with barcode students such as the teacher showing a picture of a culture in Indonesia, the teacher briefly describing the diversity of cultures in Indonesia, the teacher dividing students into groups, the teacher explaining the rules of the game Traditional Tumbawa in group learning, The teacher distributes cultural picture cards in Indonesia and regional (provincial) barcode cards in Indonesia. on the tumbawa board pairs of cultural picture cards in Indonesia and barcode cards with regional images (provinces) in Indonesia, the teacher gives a limited time to students and stops the game according to the set time limit, the teacher checks the results of the group work that has been pasted there is a tumbawa board.

The teacher's activities in the learning process using the Barcode Student Tumbawa Traditional Game in the first cycle, are shown based on the observation sheet of observations of teacher activities in the first cycle in learning with the use of the traditional tumbawa game showing 22 aspects of observation with a very good score of 3 aspects or $13 \%$, the score is good 8 aspects or $37 \%$, the score is enough 7 aspects or $32 \%$, and the score is less 4 aspects or $18 \%$. The results of the analysis of the observations of teacher activities in learning were not as expected so that it affected the results of observations of student activity in learning in the first cycle of 20 observation aspects, with very good scores of 3 aspects or 15\%, good scores of 5 aspects or $25 \%$, sufficient score 8 aspects or $40 \%$ and scores less than 4 aspects or $20 \%$. 


\section{Student Learning Outcomes in Cycle I}

The low achievement of each aspect in observing teacher activities and student activities in learning has an effect on student learning outcomes which is described in the table as follows:

Table 1. Student Learning Outcomes in Cycle I

\begin{tabular}{|c|c|c|c|c|c|}
\hline \multirow{2}{*}{ No } & \multirow{2}{*}{ Frequency } & \multirow{2}{*}{ Value Range } & \multirow{2}{*}{$\begin{array}{l}\text { Percentage of } \\
\text { Acquisition }\end{array}$} & \multicolumn{2}{|c|}{ Completion } \\
\hline & & & & Yes & No \\
\hline 1 & - & $91-100$ & - & & \\
\hline 2 & 1 person & $83-90$ & $7 \%$ & $\sqrt{ }$ & \\
\hline 3 & 6 People & $74-82$ & $40 \%$ & $\sqrt{ }$ & \\
\hline 4 & 8 People & $<74$ & $53 \%$ & & $\sqrt{ }$ \\
\hline & \multicolumn{2}{|c|}{ Classical Completeness } & $47 \%$ & & \\
\hline
\end{tabular}

Based on the table above, it can be seen that student learning outcomes in cycle I have not met the completeness criteria with a percentage of $75 \%$ of all total students. Because of the 15 students, there were only 7 students, or $47 \%$ obtained the complete criteria while 8 people or 53\% did not complete. From the results of student learning in the cycle, I learning still have not reached the completeness target planned. Therefore it will be continued in the next action.

The accumulation of the results of observations of teacher activities, student activities, and student learning outcomes in cycle I is illustrated in the following diagram:

Table 2. Observation Results and Learning Outcomes of the Use of Traditional Tumbawa Games based on Barcode Cycle I

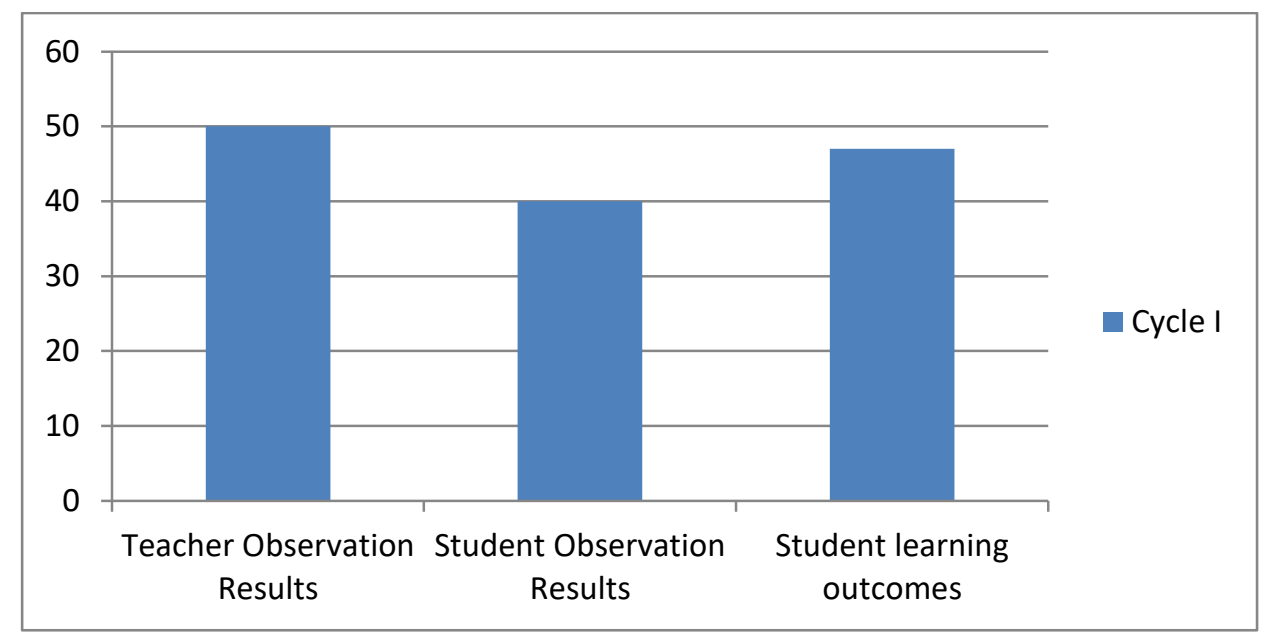

\section{Reflection Cycle I}

Based on the description of the research results in cycle I, the researcher reflected by reobserving the results of each observation of teacher and student activities in the PPKn learning process using the Barcode-based traditional Tumbawa game. Reflection produces some information related to a lack of action in cycle I. Based on the results of observations of teacher activities in learning in cycle I, of the 22 observed aspects, there are still 11 aspects or $50 \%$ that have not been implemented properly, as is the observation of student activities in learning from 20 There are 12 aspects observed or $60 \%$ that have not been achieved. This has an effect on student learning outcomes, namely out of 15 students there were only 7 students or $47 \%$ who completed while 8 people or $53 \%$ did not complete. From the results that have not reached the indicators of success, the research is continued in cycle II. 


\section{Results of Teacher Observations and Student Activities in Using Barcode-Based Traditional Games Tumbawa Cycle II}

The plan in learning action in cycle II is based on the results of reflection on the implementation of the action in cycle I. In planning in cycle II, the researchers did several things including preparing the PPKn material to be taught, rearranging the lesson plans by focusing on the use of Barcode-based traditional Tumbawa games. , as well as preparing other supporting media in the learning process, such as cultural picture cards in Indonesia, barcode names of regions in Indonesia, making observation sheets for teacher activity observations, observation sheets for student activity observations, and tests as evaluation materials to obtain student learning outcomes.

In the implementation of learning cycle II by using the traditional game tumbawa with student barcode, the teacher takes steps at the core of learning such as: (1) the teacher shows a picture of culture in Indonesia, (2) The teacher explains briefly about cultural diversity in Indonesia, (3) The teacher shares students into groups, (4) The teacher explains the rules of the traditional Tumbawa game in group learning, (5) The teacher distributes cultural picture cards in Indonesia and regional (provincial) barcode cards in Indonesia, (6) In groups of students look for pairs of picture card cards culture in Indonesia and regional (provincial) barcode cards in Indonesia, (7) Each group sticks to the tumbawa board pairs of cultural picture cards in Indonesia and regional (provincial) barcode cards in Indonesia, (8) The teacher gives limited time to students and stop the game according to the predetermined time limit, (9) The teacher checks the results of the work of the group ok that has been posted on the tumbawa board, (10) The teacher reflects on each group at the end of the game, (11) The teacher asks questions and answers with students, related to the material with students.

Based on the analysis of the results of learning observations in cycle II with the use of barcode-based traditional games tumbawa on PPKn learning from 22 aspects of observation, there are 8 aspects or $36 \%$ get very good categories, 11 aspects or $50 \%$ with good categories and 3 aspects or $14 \%$ with sufficient categories. So that the accumulated results of the very good and good categories get a result of $86 \%$. From the increase in the observed aspects of teacher activities in learning, it has a significant impact on student activities in learning. This can be seen from 20 aspects of observation, there are 8 aspects or $40 \%$ get very good categories, 10 aspects or $50 \%$ get enough categories, and 2 aspects or $10 \%$ get enough categories. So that the results of the accumulated category are very good and good reaching $90 \%$. Thus the observation of teacher activities and student activities in learning in cycle II shows an increase as expected.

\section{Student Learning Outcomes in Cycle II}

The implementation of the second cycle of learning, from the observations, shows an improvement in the learning process carried out by the teacher, so it has a good impact on students when receiving learning. The improvement of student learning outcomes in learning is described in the table of student learning outcomes in the following cycle II.

Table 2. Student Learning Outcomes in Cycle II

\begin{tabular}{|c|c|c|c|c|c|}
\hline \multirow{2}{*}{ No } & \multirow{2}{*}{ Frequency } & \multirow{2}{*}{ Value Range } & \multirow{2}{*}{$\begin{array}{c}\text { Percentage of } \\
\text { Acquisition }\end{array}$} & \multicolumn{2}{|c|}{ Completion } \\
\hline & & & & Yes & No \\
\hline 1 & 5 People & $91-100$ & $33 \%$ & & \\
\hline 2 & 7 People & $83-90$ & $47 \%$ & $\sqrt{ }$ & \\
\hline 3 & 1 Person & $75-82$ & $7 \%$ & $\sqrt{ }$ & \\
\hline 4 & 2 People & $<75$ & $13 \%$ & & $\sqrt{ }$ \\
\hline & \multicolumn{2}{|c|}{ Classical Completeness } & $87 \%$ & & \\
\hline
\end{tabular}


Based on the description of the table of student learning outcomes in cycle II above, it can be seen that the learning outcomes of cycle II students have increased from the results of previous learning. Student learning outcomes in cycle II of 15 students, there were 13 students, or $87 \%$ obtained the complete criteria while 2 people or $13 \%$ did not complete. From the results of student learning outcomes in the cycle, II learning has reached the expected success indicator target.

\section{Reflection Cycle II}

In the implementation of the second cycle of learning with the use of barcode-based traditional games tumbawa in PPKn learning, from the observations the teacher has carried out learning according to the steps in the barcode-based traditional game of tumbawa so that the learning is more attractive to students when learning.

Learning PPKn with the use of barcode-based traditional games tumbawa provides good student learning outcomes with the achievements of 15 students, there are 13 students or $87 \%$ get complete criteria while 2 people or $13 \%$ do not complete. The results of student learning in cycle II has reached indicators of success.

Learning is a complex process that happens to everyone and lasts a lifetime. One of the signs that someone has learned something is a change in behavior in him. Student learning outcomes are the achievement of learning objectives through a teaching and learning process about teaching materials. In principle, the disclosure of ideal learning outcomes includes all psychological domains that change as a result of students' learning experiences and processes. However, it is very difficult to reveal changes in the behavior of all these domains, especially the realm of students' feelings. The results showed that the observation of teacher activities and student activities in learning in cycle II showed an increase as expected. Barcode-based traditional tumbawa games make learning more interesting and show students' enthusiasm when learning.

\section{Conclusion}

Based on the results of the analysis of student learning in the first and second cycles above, it can be concluded that the barcode-based traditional game of tumbawa in PPKn (Citizenship Education) learning can improve student learning outcomes. Achievement of student learning outcomes in cycle II of 15 students, there were 13 students or $87 \%$ obtained complete criteria while 2 people or $13 \%$ did not complete. In the use of traditional games based on tumbawa, the teacher must help and supervise so that students do not have difficulty understanding the rules in barcode-based tumbawa games.

\section{References}

Achroni. K. (2012). Mengoptimalkan Tumbuh Kembang Anak Melalui Permainan Tradisional. Yogyakarta: Javalitera.

Arikunto, S. (2010). Penelitian Tindakan untuk Guru, Kepala Sekolah dan Pengawas. Yogyakarta: Aditya Media.

Daley, D. M. (2012). Strategic human resources management. Public personnel management, $120-125$.

Daulima, F. (2006). Permainan Anak Tradisional Daerah Gorontalo. Gorontalo: Forum Suara Perempuan.

Dharmamulya, S. (2005). Permainan tradisional jawa. Kepel Press. 
Dussault, G., \& Dubois, C. A. (2003). Human resources for health policies: a critical component in health policies. Human resources for health, 1(1), 1.

Husain, F. A. (2013). Survei Permainan Tradisional dalam Pembelajaran Penjasorkes pada Siswa di Sekolah Dasar se-Kecamatan Brangsong Kabupaten Kendal. Thesis, dissertation, Universitas Negeri Semarang.

Kemmis, S., McTaggart, R., \& Nixon, R. (2013). The action research planner: Doing critical participatory action research. Springer Science \& Business Media.

Kurniati, E. (2016). Permainan tradisional dan perannya dalam mengembangkan keterampilan sosial anak. Kencana.

Narasimhan, V., Brown, H., Pablos-Mendez, A., Adams, O., Dussault, G., Elzinga, G., ... \& Sewankambo, N. (2004). Responding to the global human resources crisis. The Lancet, 363(9419), 1469-1472.

Sujarno. (2013). Pemanfaatan Permainan Tradisional dalam Pembentukan Karakter Anak. Yogyakarta: Balai Pelestarian Nilai Budaya (BPNB).

Yudiwinata, H. (2014). Permainan tradisional dalam budaya dan perkembangan anak. Paradigma, 2(3). 